\title{
Work Capacity of the Elderly: Assuming Another Social Identity in the Contemporary World
}

\author{
João Henrique de Morais Ribeiro, Raul Paiva dos Santos, Deusdete Inácio de Souza Junior, \\ Daniele Sirineu Pereira, José Vitor da Silva, Maria Angélica Mendes
}

Escola de Enfermagem da Universidade Federal de Alfenas (UNIFAL/MG), Alfenas, Brazil
Email: enf.joaoh@gmail.com

Received 31 August 2015; accepted 9 October 2015; published 14 October 2015

Copyright (C) 2015 by authors and Scientific Research Publishing Inc.

This work is licensed under the Creative Commons Attribution International License (CC BY).

http://creativecommons.org/licenses/by/4.0/

(c) () Open Access

\section{Abstract}

This is a theoretical study on the work capacity of elderly people based on the Social Identity Theory-SIT. In that perspective, work capacity can be considered as the result of a dynamic process. It refers to the worker's skills to execute professional activities according to the job requirements and his/her health condition. The SIT aims to highlight the existing impact on people's behavior when they find themselves members of social categories and, therefore, it involves the operation of three psychological processes, which are: social categorization, social identification and social comparison. Thus, one can assume that society characterizes the elderly people as belonging to the retired group, and from a capitalist perspective, considers these people as unproductive. Their identity is linked to workers who are active in the job market; in addition, the chronological determinant of age does not impede elderly people from continuing in the job market. When elderly people are considered capable of developing their activities, whether professionally or not, and start to play new social roles, the start of the transformation in the conception of old age is perceived. In view of this panorama, a Conceptual Theoretical base is proposed, aiming to locate the phenomenon "work capacity" inside the aging process as this capacity is centered on the advanced activities of daily living.

\section{Keywords}

Aged, Social Class, Social Behavior, Work Capacity Evaluation

\section{Introduction}

This study emphasizes the work capacity of elderly people based on the proposals of the Social Identity Theory

How to cite this paper: de Morais Ribeiro, J.H., dos Santos, R.P., de Souza Junior, D.I., Pereira, D.S., da Silva, J.V. and Mendes, M.A. (2015) Work Capacity of the Elderly: Assuming Another Social Identity in the Contemporary World. Open Journal of Social Sciences, 3, 24-32. http://dx.doi.org/10.4236/jss.2015.310004 
(SIT). In that perspective, population aging is a heterogeneous and multifactorial phenomenon, deriving from conquests in the social, technological and health areas. These have led to relevant transformations in the age structure of the global population, as well as in the socioeconomic characteristics of developed and developing countries [1] [2]. This phenomenon also conditioned the aging of the workforce, influencing the economically active population and, thus, occupational health, work capacity and retirement matters started to be the focus of research against the background of the globalization and productive restructuring [3] [4].

Work capacity can be conceived as the result of a dynamic process, which refers to the workers' skills to execute professional activities according to the occupational requirements and their health conditions [5] [6]. Different factors, including demographic characteristics, lifestyle, aging and work requirements, can compromise that capacity and make it unsatisfactory across the lifetime. In that sense, measures to maintain the work capacity should comprise proposals to improve the conditions of life and the work environment, with a view to greater productivity and a better quality of life inside and beyond organizations [4]-[7].

In the capitalist world, characterized by production, agility, modernity, competitiveness and profit imperatives, mistrust towards the performance of elderly people's social roles is frequent, whom the public sees as fragile, dependent and unproductive, to the extent of being considered as a "burden" for the new generations. Thus, senescence is a social and cultural construction that rests on mistaken myths and stigmas, leading to the social marginalization of elderly people, even if disguisedly, and to the non-prioritization of their rights [8] [9]. In addition, the meaning of work is associated with active performance, a more intense rhythm, income generation, which comes with greater physical, mental and social requirements [10]. And the age factor is considered as a determinant of exclusion from the job market [11].

Nevertheless, limitations and incapacities are not exclusive to aging people, as children, young people and even adults can present loss of autonomy and functional losses, related to different health conditions. In that context, the relation between old age and incapacity is characterized as harmful. This stigma can make aging people deny their own identity and difficulties to cope with aging [12].

The scientific and social relevance of investigating issues is related to the work capacity as well as the factors associated with quality of life and welfare the elderly is providing input for creating policies alternative and interventionists of the health areas, social security, academia, public and private organizations, besides meeting the demands of an aging population.

Hence, the objective in this theoretical study is to reflect on the work capacity of elderly people and their social identity.

First, work capacity, its predictive factors and its relation with elderly people are briefly presented, evidencing conditions that can limit or promote that capacity. Next, the Social Identity Theory is discussed, as well as the integration between that theory and the work capacity of elderly people. Finally, the need to rethink aging and promote another identity for elderly workers is discussed.

\section{Work Capacity and Elderly People}

Work capacity (WC) refers to how well workers are or will be, at present or in the near future, and how capably they can accomplish their professional activities in function of the work demands, health condition and physical and mental capacities [13]. In that sense, WC is a condition that results from the combination of human resources with the physical, mental and social demands of work, the organizational culture and the work environment [6]-[14]. Hence, maintaining the WC entails positive consequences for health, wellbeing and employability; offering benefits for the employment institution as well as for society.

Predictive factors of WC should be highlighted, revealing a promising area for interventions to maintain that capacity in the evident and accelerated aging process. These factors can be grouped in three categories, which are [15]:

1) factors related to the individual, such as age, marital status, perceived health, habits and lifestyle;

2) factors related to work, such as the bodily and intellectual demands, ergonomic and environmental processes involving the organization and the workplace and, finally,

3) factors related to life beyond work, including the worker's family and social network, as well as their wellbeing and personal satisfaction.

These dynamically and mutually related predictors favor mechanisms to promote and preserve the WC and demonstrate areas that need further actions to maintain WC in the course of the workers' aging process [15] [16]. 
Population aging entails a considerable increase in social spending [17] due to the greater demand for health services, more frequent hospitalizations with longer bed occupancy when compared to other age ranges [18]. In addition, the advantages of retirement, the loss of an acknowledged and valued social role and the early exit from professional life can provoke severe consequences in the elderly people's individual and social dimensions. Therefore, early retirement, unemployment and physical incapacity have been related with worse health conditions, greater prevalence of harmful habits and psychiatric symptoms, besides higher mortality rates [19] [20].

The impact of aging on the functionality of elderly individuals depends on some factors, including genetics, lifestyle and presence of chronic illnesses. The decline in functional capacity can take place after the age of 45 years old, increasing by $12 \%$ each year, being further enhanced at the age of 50 . This decline can affect the work capacity and the workers' productivity. This impact is generally more frequent in professions that pose greater physical demands in comparison with occupations that require more mental activity [14]-[22].

The factors that limit elderly people's work capacity are related to the presence of chronic illnesses, sedentariness, obesity, heavy physical workload and discrimination of elderly workers in the job environment. These can enhance the risk of illness and extended absences from professional activities and favor these workers' economic inactivity. On the other hand, promoting health and vitality, learning and new skills development and making adjustments in the physical and psychosocial work environment can help elderly workers to avoid illnesses, guarantee better cognitive and physical skills and can provoke positive attitudes towards the aging process and quality of life, thus promoting their work capacity [23] [24].

Promoting elderly people's work capacity is directly related to the adaptation process of work to the elderly workers' capacities, competences and health conditions. This permanent and dynamic process rests on the cooperation between company and worker and on the assessment of occupational risks. This adaptation processshould not be considered as an additional burden, as age is but one aspect of the workforce diversity. The cooperation between companies and elderly workers can strengthen their work capacity and keep them productive, besides favoring a positive view on life and their competences as workers. When these cooperation and adaptation actions are not effective, the workers lose their space in the work environment, which contributes to increasing diseases and stress and reduce the purchasing power, due to a lack of opportunities for career and educational progress, as well as due to difficulties to adapt to new technologies and re-enter the job market [23]-[25].

In the contemporary world, "health promotion" evidences the subjects' protagonist role in the Social Determinants of Health, the latter being considered as the result of the relation between quality of life, food and nutrition, housing and sanitation, good work conditions, education opportunities across the lifetime, a clean physical environment, social support to families and individuals and a responsible lifestyle and appropriate set of healthcare actions. Health promotion activities are therefore aimed at the group of individuals and at the physical, social, political, economic and cultural environment, through public policies and conditions that are favorable to the health and empowerment of individuals and communities [26].

Thus, the functional capacity emerges as a new paradigm in the health of elderly people, furthering an independent and autonomous life that is capable of maintaining the capacity to perform the basic, instrumental and advanced activities of daily living, such as personal hygiene, washing, dressing, preparing one's meals, feeding, continence, housekeeping, buying, using the telephone and transferring, walking, controlling finances, among others [27].

\section{The Social Identity Theory}

Elaborated with a focus on group processes and phenomena that are relevant to inter-group relations, the SIT intends to highlight the existing impact on people's behavior when they find themselves members of social categories. It results in the search to maximize the inter-group differences and intra-group similarities, such as behaviors, knowledge and emotions [28] [29]. It is characterized as a psychological and social judgment of the role of a group of people's self-conception related to the group processes and their inter-group relations. The SIT comprises interrelated concepts and small Theories focused on the cognitive-social and motivational aspects in the social and macro-social interaction of a group's life. Its approach is structured on the conviction that a collective phenomenon cannot be appropriately discussed in terms isolated from individual processes or only from interpersonal relations [30].

According to the SIT, "social group" is the interaction between two or more people who find themselves and are perceived as such by the other members of the same social category, and who somehow share feelings and 
emotions resulting from this shared belonging. The "group" is the first socius of the individual; besides constituting the base for the establishment of the social identity. It is in the group that people internalize their beliefs, establish expectations of self-efficiency, have possibilities to enhance or mitigate their lives, which can depend on their position in society and on the protection networks they are inserted in [31]. Thus, a "group" is socially considered while a social consensus exists inside and outside that group about what it represents and which are the characteristics needed to belong to it [29]. Human interaction varies from a purely interpersonal spectrum on the one hand to a purely intergroup spectrum on the other. Strictly interpersonal interaction involves people totally related with individuals, without any awareness of their social category. In strictly intergroup interaction, then, people are totally related with representatives of their "group" [32]. In that sense, the "group" will only continue to exist if there are people presenting the latter behavior.

The acknowledgement of belonging to a "group" is related to some factors, among which the following stand out; people choose a new "group" when it contributes to improvements in the positive aspects of their social identity; or leave the "group" when it does not contribute to their identity. In those cases in which they cannot drop out of the "group", the person can reinterpret its attributes, making them more acceptable, or make efforts to improve the position of the "group" in society [33].

The SIT contains three fundamental and mutually articulated elements, which are: motivation to acquire a positive social identity; the difference in status among specific groups in society; and the possibility of people dealing with difficulties associated with that identity through individual or group strategies [34]. The group processes, however, originate in people's motivation to achieve, maintain and strengthen a positive self-image, outlined based on the set of concepts people have at their disposal to identify themselves, whether as individuals or members of a certain "group". The part of the I that derives from the belonging to groups corresponds to the social identity. Thus, people will make efforts for this identity to be positive, which can be achieved through the positive distinction of the endogroup— "group" the person belongs to" from the exogroup—other people's "group" [33] [34]

According to the SIT, the construction of the "social I" involves the operation of three psychological processes, which are: social categorization, social identification and, finally, social comparison.

1. Social categorization - cognitive process that aims to understand the environment and establishes a classification scheme, in which objects and people are separated based on shared characteristics [31]; this process if fundamental to allow people to cope and relate with the complex social world [29]. The function of the categorization is the organization of information received from the environment, which can facilitate people's orientation in their social reality. It is through the characterization that cognitive stereotypes are established, when referring to the preservation of the value system; and ideological stereotypes when referring to the preservation of the distinction in relation to other groups [35].

2. Social identification - results in the perception people have when they belong to a certain social category. Nevertheless, belonging to a "group" does not turn the social category into an identification; for that purpose, the person needs to accept and adopt the belonging to the "group" as self-defining; the "group" needs to attribute meaning, importance and value to the person and, finally, the group members need to acknowledge that belonging [28]. To define a social identity, three components need to be articulated, which are: cognitive, which remits to the categorization and belonging to a social group: evaluative, associated with the social value of belonging to the "group", followed by the emotional, which corresponds to the emotions produced by the value attributed by other people and by the individual to the "group" (s)he belongs to [36].

3. Social comparison-psychological process employed to define the social identity, especially the value of this group identity. As people define themselves as belonging to a "group" and the group defines them as members, they exhibit a value of belonging, that is, a value for their social I, which derives from the comparison of their "group" with the others. In that sense, people look for a positive social identity in this process of comparison with other groups, in the attempt to belong to socially valued groups. Thus, people share some kind of emotional involvement with a certain "group" before they consider themselves part of it [35].

Therefore, there is a relevant relation between the categorization and social comparison processes, as the categorization creates and defines people's place in society; and the comparison attributes an objective nature to the categorization, resting on the person's belonging to a concrete social group [37].

\section{The Social Identity Theory and the Work Capacity in Elderly People}

The concepts of the SIT can offer great contributions to study the theme work capacity of elderly people. In ad- 
dition, the theory can offer opportunities to understand the adhesion to social groups, as well as the articulations needed to belong to and be perceived by the "group".

Regarding the work capacity of elderly people, using the concepts of the SIT, one can assume that:

$\checkmark$ The chronological determinant of age does not impede elderly people from remaining in the job market, as the aging process is heterogeneous and multifactorial, and age is but one of the dimensions used when planning actions for this age group;

$\checkmark$ The globalized society considers elderly people characterized by lacks. To give an example: in the technological world, elderly people lack young people's skill to handle the technologies, even typing; nevertheless, elderly people can offer informed experience to enhance these young people's work. In short, there is always something lacking for elderly people to be truly included in the social work group;

$\checkmark$ In the modern society, the group of workers demands strength, skills to develop technological activities and agility. Elderly people can present greater knowledge when compared to young people, greater concentration, responsibility, commitment and willingness to face new challenges and learning;

$\checkmark$ The marginalized and lacking stigma, whether due to the personal characteristics or the "absence" of a productive role, can be attributed to the elderly individuals, which nurtures the discrimination by younger people;

$\checkmark$ The cultural differences can interfere in elderly people's adhesion to social groups. In Eastern countries, "being old" is related to wisdom and respect by social members, a situation that favors the valuation of elderly individuals. In Western countries like Brazil, the social representation of elderly people is related to depreciative factors like illnesses, uselessness and social burden;

$\checkmark$ Society characterizes elderly people as belonging to the retired group which, from the capitalist perspective, considers these people as unproductive, having their identity linked to that of workers who were active in the job market, but are not active anymore recently and receive social benefits;

$\checkmark$ The social identity is constructed through the connection the individual makes with society. Elderly individuals need to use different strategies to identify themselves as workers and seek recognition and belonging in that social group;

$\checkmark$ The social classification as workers favors elderly people's self-esteem and participation in society, reaffirming their value as persons and community members;

$\checkmark$ By classifying themselves as belonging to the group of workers, elderly people start to assume values of the social group as self-defining and expect the other "group" members to recognize their belonging. When recognized, they start to seek a positive social identity and improve the group's position in society. This feeling of belonging promotes a valuation of elderly workers in society;

$\checkmark$ In organizations, belonging to a certain group can symbolize protection for elderly people, besides favoring creativity and performance at work;

$\checkmark$ The aging process associated with professional activity, learning, flexibility, personal satisfaction, besides new bonds, favors the positive social identity; as a consequence of the elderly people's valuation due to their new habits, images and practices;

$\checkmark$ In the context of the social identity, elderly workers tend to seek changes in the attributes of this social group they are inserted in, revealing to society that they are capable of staying in the market and in the workforce;

$\checkmark$ A healthy intragroup relationship can strengthen elderly individuals' participation in the job market and support the positive identity of the "group" they belong to.

\section{Rethinking Aging and Promoting Another Social Identity for Elderly People}

Aging by itself is conceived as a synonym of disease, disability and losses, deriving from the attachment to outdated and crystallized values that also lead to social isolation; this conception is rooted in the course of history, multiplied in the contemporary reality and assumed by these elderly. In post-modern times, the cult of the young, beautiful and curvy body embarrasses the understanding of aging and its multiple dimensions, thus contributing to the harmful and marginalizing conception of elderly people. The expressions "elderly people can't hear well" or "they don't know anything about informatics" or "inflexible, strict and boring old man" are commonly used. This behavior denounces the classification of elderly people as "lacking", imposing barriers forthe development of new skills; as there supposedly is no more time left to invest in them. In that context, one of the consolidated characteristics in our tradition is the "horror of old age" [38] [39]. 
The aging experience has been changing in recent years, so that clear transformations in its social image can be observed; in the different possibilities of getting new experiences, as well as the challenges these extra years lived offer to individuals and society [40]. Thus, individuals can recognize and construct aging in different ways; this construction will depend on how people observe aging and how it is perceived by each of us: aging labeled as losses or as a "new" phase of wholeness and capacities [41].

The advance of the aging process reveals behaviors, customs and beliefs that significantly change the conceptions that link aging to a period for rest, serenity and inactivity. This gives rise to an identity model that stimulates activity, learning, expectations of personal satisfaction, besides favoring the creation of bonds this age group had never experienced [42].

The flexibility and willingness to learn are now two identity characteristics that are contemporary determinants in the construction of personal identities. In the business context, these characteristics are essential for people to be successful in professional as well as social and affective matters [43]. Hence, when elderly people transform their reality, they can find different possibilities to act and put in practice their image as new social agents, willing to claim their fundamental rights and fight for space and respect in society [12].

When elderly people are considered capable of developing their activities, whether professionally or not, and start to play new social roles, the start of the transformation in the conception of old age is perceived. These people who used to be considered incapable, vulnerable and useless assume their role as active social agents, showing another social identity - that of capable elderly, incorporating the search for wellbeing, work and quality of life in society in their activities [44]. The construction and adoption of this social identity lacks welcoming, understanding and support from the entire society, not only the job world, aiming to offer support to the elderly to reconsider and assume the social roles, to cope with possible limitations and adversities in the elaboration of the new life projects, thus authorizing successful aging [45].

In view of that panorama, a Conceptual Theoretical base (Figure 1) is proposed to situate the phenomenon "work capacity" in the aging process, as that capacity is centered on the advanced activities of daily living, that is, on productive, leisure and social activities [46].

Thus, through the promotion and integrated and harmonious maintenance of the functional systems, elderly people can perform the different activities in life, playing their role as workers and affirming this other social identity [46].

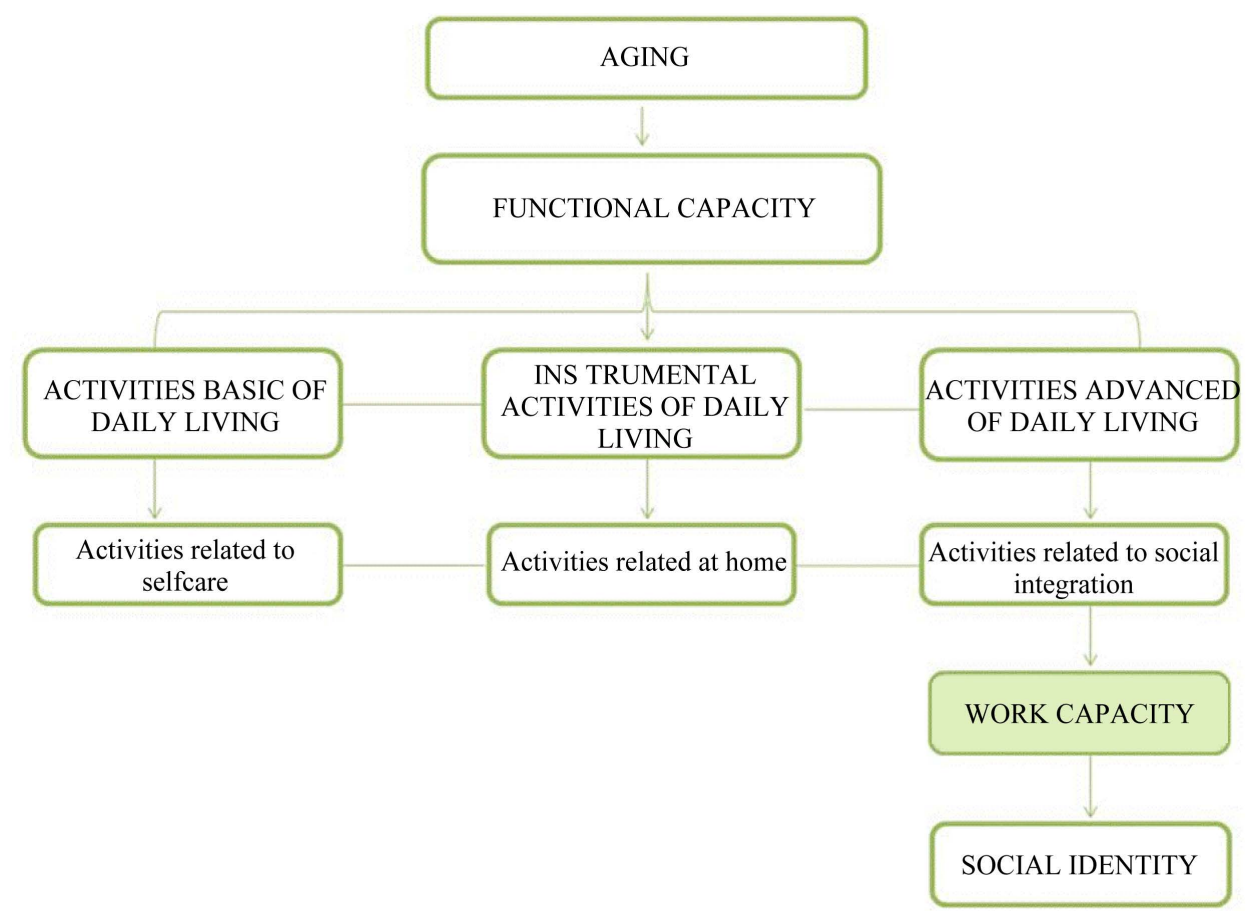

Figure 1. Theoretical base of the phenomenon "work capacity in elderly people". Alfenas, Brazil, 2014. Source: The author. Adapted from Activities of Daily Living. Moraes, 2012. 


\section{Final Considerations}

The aging process has aroused and transformed meanings and representations of elderly people and their relation with the social context, going against the traditional discourse of aging marked by isolation, sadness, losses and lack of perspective in life [47].

In the western culture, work represents one of the pillars of self-esteem, the assertion of identity through success and satisfaction with one's professional activities, as well as the sense of utility, which can be considered as a fundamental element in the organization of life. Losing this bond can entail difficulties that threaten people's quality of life, favoring the emotional and social disequilibrium, the adoption of sedentary attitudes, chemical addiction and inappropriate eating habits [48] [49].

In that context, the different social actors involved with elderly people are responsible for maintaining the functional and work capacity, with a view to guaranteeing their continuation in the social space. Therefore, managers, health professionals and the academy should establish health indicators that permit the identification of elderly people at increased risk of functional losses [50]. Thus, interventions can be promoted that favor the functional independence, with a cost-benefit relation compatible with the resources the Unified Health System (SUS) makes available. These interventions, based on the Health Promotion perspective, can further the individuals' autonomy for health care and the adoption of healthy daily habits, also at work.

Similarly, the adoption of a policy to maintain the work capacity should be encouraged in organization, including proposals aimed at removing age barriers in the workplace, in the increased flexibility of the hour load, in the encouragement of physical exercise and healthy eating, besides financial incentives to drive these elderly workers' active participation. These proposals are assertive and fundamental from the current perspective of changes in the production and in the work relations [51]-[53].

Finally, investing in the functional independence and work capacity of elderly people is fundamental as a response to cope with the advanced population aging process. In addition, by guaranteeing elderly people's reinsertion and maintenance in the job market, the new discourse on aging can be strengthened, these elderly people's empowerment with regard to their social identity can be promoted and their rights can be guaranteed.

\section{Acknowledgements}

Coordenação de Aperfeiçoamento de Pessoal de Nível Superior, CAPES, Brasil.

Fundação de Apoio à Pesquisa do Estado de Minas Gerais, FAPEMIG. Process APQ-00088-14.

\section{References}

[1] Lebrão, M. L. (2007) O envelhecimento no Brasil: aspectos da transição demográfica e epidemiológica. Saúde Coletiva, 4, 135-140. https://www.nescon.medicina.ufmg.br/biblioteca/imagem/2559.pdf

[2] Wong, L.L.R. and Carvalho, J.A.M. (2006) The Rapid Process of Aging in Brazil: Serious Challenges for Public Policies. Revista Brasileira de Estudos de População, 23, 5-26. http://dx.doi.org/10.1590/S0102-30982006000100002

[3] Andrade, C.B. and Monteiro, M.I. (2007) Aging and Work Ability of Workers of a University Hospital's Cleaning and Hygiene Service. Revista da Escola de Enfermagem da USP, 41, 237-244. http://dx.doi.org/10.1590/S0080-62342007000200009

[4] Martinez, M.C., Latorre, M.R.D.O. and Fischer, F.M. (2010) Work Ability: A Literature Review. Ciência e Saúde Coletiva, 15, S1553-S1561. http://dx.doi.org/10.1590/S1413-81232010000700067

[5] Silva, L.G., Haddad, M.C.L., Domansky, R.C. and Vituri, D.W. (2010) Work Ability among Cleaning and Hygiene’s Workers of a Public University Hospital. Rev. Eletr. Enf., 12, 158-163.

[6] Martinez, M.C. and Latorre, M.R.D.O. (2006) Health and Work Ability among Office Workers. Revista de Saúde Pública, 40, 851-858. http://dx.doi.org/10.1590/S0034-89102006000600015

[7] Tuomi, K., Ilmarinen, J., Jahkola, A., Katajarinne, L. and Tulkki, A. (2005) Índice de capacidade para o trabalho. Traduzido por Frida Marina Fischer. EdUFSCar, São Carlos.

[8] Schneider, R.H. and Irigaray, T.Q. (2008) The Process of Aging in Today's World: Chronological, Biological, Psychological and Social Aspects. Estudos de Psicologia (Campinas), 25, 585-593.

[9] Almeida, T. and Lourenço, M.L. (2009) Reflexões: Conceitos, estereótipos e mitos acerca da velhice. Revista Brasileira de Ciências do Envelhecimento Humano (RBCEH), 6, 233-244. http://dx.doi.org/10.5335/rbceh.2009.022 http://www.upf.br/seer/index.php/rbceh/article/view/171 
[10] Alcântara, A.O. (2009) Velhos institucionalizados e família: entre abafos e desabafos. Editora Alínea (Coleção velhice e sociedade), Campinas.

[11] Giaqueto, A. and Soares, N. (2010) O trabalho e o trabalhador idoso. Anais do VII Seminário de Saúde do Trabalhador e V Seminário O Trabalho em Debate "Saúde Mental Relacionada ao Trabalho", Franca. http://www.proceedings.scielo.br/pdf/sst/n7/a07.pdf

[12] Scortegagna, P.A. and Oliveira, R.C.S. (2012) Idoso: Um novo ator social. Anais do IX Seminário de Pesquisa em Educação da Região Sul, Caxias do Sul. http://www.ucs.br/etc/conferencias/index.php/anpedsul/9anpedsul/paper/viewFile/1886/73

[13] Fischer, F.M. (2005) Breve histórico desta tradução. In: Tuomi, K., Ilmarinen, J., Jahkola, A., Katajarinne, L. and Tulkki, A., Org., Índice de capacidade para o trabalho, EduFSCar, São Carlos.

[14] Ilmarinen, J.E. (2001) Aging Workers. Occupational and Environmental Medicine, 58, 546-551. http://dx.doi.org/10.1136/oem.58.8.546

[15] Sampaio, R.F. and Augusto, V.G. (2012) Aging and Work: A Challenge for the Rehabilitation Schedule. Brazilian Journal of Physical Therapy, 16, 94-101. http://dx.doi.org/10.1590/S1413-35552012000200003

[16] Amorim, J.S.C., Salla, S. and Trelha, C.S. (2014) Factors Associated with Work Ability in the Elderly: Systematic Review. Revista Brasileira de Epidemiologia, 17, 830-841. http://dx.doi.org/10.1590/1809-4503201400040003

[17] Strijk, J.E., Proper, K.I., Van der Beek, A.J. and Van Mechelen, W. (2009) The Vital@Work Study. The Systematic Development of a Lifestyle Intervention to Improve Older Worker's Vitality and the Design of a Randomized Controlled Trial Evaluating This Intervention. BMC Public Health, 9, 408. http://dx.doi.org/10.1186/1471-2458-9-408

[18] Veras, R.P. (2009) Population Aging Today: Demands, Challenges and Innovations. Revista de Saúde Pública, 43, 548-554. http://dx.doi.org/10.1590/S0034-89102009000300020

[19] Mendes, M.R.S.S.B., Gusmão, J.L., Mancussi e Faro, A.C. and Leite, R.C.B.O. (2005) The Social Situation of Elderly in Brazil: A Brief Consideration. Acta Paulista de Enfermagem, 18, 422-426. http://dx.doi.org/10.1590/S0103-21002005000400011

[20] Ilmarinen, J.E. and Rantanen, J. (1999) Promotion of Work Ability during Ageing. American Journal of Industrial Medicine, 36, S21-S23. http://dx.doi.org/10.1002/(sici)1097-0274(199909)36:1+<21::aid-ajim8>3.0.c0;2-s

[21] Padula, R.S., Comper, M.L., Moraes, S.A., Sabbagh, C., Pagliato, W.J. and Perracini, M.R. (2013) The Work Ability Index and Functional Capacity among Older Workers. Brazilian Journal of Physical Therapy, 17, 382-391. http://dx.doi.org/10.1590/S1413-35552013005000107

[22] Tuomi, K., Ilmarinen, J., Klockars, M., Nygård, C.H., Seitsamo, J., Huuhtanen, P., et al. (1997) Finnish Research Project on Aging Workers in 1981-1992. Scandinavian Journal of Work, Environment \& Health, 23, S7-S11. http://www.sjweh.fi/show_abstract.php?abstract_id=207

[23] Ilmarinen, J.E. (2012) Promoting Active Ageing in the Workplace. European Agency for Safety and Health at Work, Espanha. https://osha.europa.eu/pt/priority groups/ageingworkers

[24] Ribeiro, J.H.M. (2014) Capacidade para o trabalho da pessoa idosa: Caracterizando uma outra identidade social. Dissertação de Mestrado, Universidade Federal de Alfenas, Alfenas. https://bdtd.unifal-mg.edu.br:8443/handle/tede/324

[25] European Agency for Safety and Health at Work-EU-OSHA (2015) Adapting Work and the Work Environment. Espanha. https://osha.europa.eu/pt/priority_groups/ageingworkers

[26] Buss, P.M. (2005) Health Promotion and Quality of Life. Ciência \& Saúde Coletiva, 5, 163-177. http://dx.doi.org/10.1590/S1413-81232000000100014

[27] Guimarães, L.H.C.T., Galdino, D.C.A., Martins, F.L.M., Abreu, S.R., Lima, M. and Vitorino, D.F.M. (2004) Functional Capacity Assessment in Elderly on Physiotherapy. Revista Neurociências, 12, 130-133. http://www.revistaneurociencias.com.br/edicoes/2004/RN\%2012\%2003/Pages\%20from\%20RN\%2012\%2003-3.pdf

[28] Hogg, M.A. and Abrams, D. (1988) Social Identifications-A Social Psychology of Intergroup Relations and Group Processes. Biddle, Guildford. https://books.google.com.br/books/about/Social_identifications.html?id=M1m8RmoippEC\&redir_esc=y

[29] Tajfel, H. and Turner, J.C. (1986) The Social Identity Theory of Intergroup Behavior. In: Worchel, S. and Austin, W.G., Eds., Psychology of Intergroup Relation, Hall Publishers, Chicago, 7-24.

[30] Hogg, M.A. (2006) Social Identity Theory. In: Burke, P.J., Ed., Contemporary Social Psychological Theories, Stanford University Press, Redwood City. http://books.google.com.br/books?id=8Jzkgbq2vYwC\&printsec=frontcover\&hl=pt-BR\#v=onepage\&q\&f=false

[31] Prette, A.D. and Prette, Z.P.D. (2003) Assertividade, Sistema de crenças e identidade social. Psicologia em Revista, 9, 125-136. http://www.pucminas.br/imagedb/documento/DOC_DSC_NOME_ARQUI20041214095307.pdf 
[32] Hornsey, M.J. (2008) Social Identify Theory and Self-Categorization Theory: A Historical Review. Social and Personality Psychology Compass, 2, 204-222. http://dx.doi.org/10.1111/j.1751-9004.2007.00066.x

[33] Tajfel, H. (1981) Human Groups and Social Categories. Cambridge University Press, New York. http://books.google.com.br/books?id=ldA8AAAAIAAJ\&printsec=frontcover\&hl=pt-BR\#v=onepage\&q\&f=false

[34] Turner, J.C. and Reynolds, K.J. (2003) The Social Identity Perspective in Intergroup Relations: Theories, Themes and Controversies. In: Brown, R. and Gaertner, S., Eds., Blackwell Handbook of Social Psychology: Intergroup Processes, Blackwell Publishers, Oxford, 133-152. http://dx.doi.org/10.1002/9780470693421.ch7

[35] Galiinkin, A.L. and Zauli, A. (2011) Identidade social e alteridade. In: Torres, C.V. and Neiva, E.R., Org., Psicologia social: Principais temas e vertentes, Artmed, Porto Alegre.

http://books.google.com.br/books?id=H-nQ_Z5LHYEC\&pg=PA27\&dq=.+Psicologia+social:+principais+temas+e+ver tentes\&hl=pt-BR\&sa=X\&ei=2WfiU8r5O5XLsQTYkoLYBQ\&ved=0CCYQ6AEwAA\#v=onepage\&q=.\%20Psicologia \%20social\%3A\%20principais\%20temas\%20e\%20vertentes\&f=false

[36] Trepte, S. (2006) Social Identity Theory. In: Bryant, J. and Vorderer, P., Eds., Psychology of Entertainment, Lawrence Erlbaum Associates Publishers, Mahwah.

http://books.google.com.br/books?id=AVnhAQAAQBAJ\&pg=PA271\&dq=TREPTE,+S.+Social+Identity+Theory\&hl =pt-BR\&sa=X\&ei=OhLxU7i5HYjksASwmoHICA\&ved=0CB0Q6AEwAA\#v=onepage\&q=TREPTE\%2C\%20S.\%20 Social\%20Identity\%20Theory\&f=false

[37] Galvão, A.C. (2009) Os muros (in) visíveis do preconceito: Um estudo das representações sociais das pessoas que vivem com HIV/aids. Dissertação de Mestrado, Universidade de Brasília, Brasília. http://repositorio.unb.br/handle/10482/7139

[38] Lasch, C. (1983) A cultura do narcisismo—A vida americana numa era de esperanças em declínios. Rio de Janeiro.

[39] Rodrigues, L.S. and Soares, G.A. (2006) Velho, idoso e terceira idade na sociedade contemporânea. Revista Ágora, No. 4, 1-29. http://periodicos.ufes.br/agora/article/view/1901/1413

[40] Silva, L.R.F. (2009) Autonomy, Imperative to Activity and "Mask of Age”: Prerogatives of Contemporary Aging? Psicologia \& Sociedade, 21, 128-134. http://dx.doi.org/10.1590/S0102-71822009000100015

[41] Almeida, S.T. (2004) Changes of the Bodily Perceptions and of the Aging Process in the Elderly Individual Belonging to the Reviver Group. RBCEH, 1, 86-98. http://www.upf.br/seer/index.php/rbceh/article/viewFile/48/40

[42] Silva, L.R.F. (2008) Third Age: New Identity, Reformulation of the Old Age or Generational Experience? Physis: Revista de Saúde Coletiva, 18, 801-815. http://dx.doi.org/10.1590/S0103-73312008000400011

[43] Sennett, R. (2002) A Corrosão do Caráter. Record, Rio de Janeiro.

[44] Camarano, A.A. and Pasinato, M.T. (2004) O envelhecimento populacional na agenda das políticas públicas. Os novos idosos brasileiros: Muito além dos 60 anos. IPEA, Rio de Janeiro.

[45] Lima, P.M.R. and Coelho, V.L.D. (2011) The Art of Aging: An Exploratory Study on Life History and Aging. Psicologia: Ciência e Profissão, 31, 4-19.

[46] Moraes, E.N. (2012) Atenção à saúde do idoso: Aspectos conceituais. Organização Pan-Americana da Saúde, Brasília. http://apsredes.org/site2012/wp-content/uploads/2012/05/Saude-do-Idoso-WEB1.pdf

[47] Ávila, A.H., Guerra, M. and Rangel Meneses, M.P. (2007) Se o velho é o outro, quem sou eu? A construção da autoimagem na velhice. Pensamiento Psicológico, 3, 7-18. http://www.redalyc.org/articulo.oa?id=80130802

[48] Canizares, J.C.L. and Jacob Filho, W. (2011) Senility Risk Factors upon Retirement Transition. Revista Brasileira de Geriatria e Gerontologia, 14, 425-432. http://dx.doi.org/10.1590/S1809-98232011000300003

[49] Magalhães, M.O., Krieger, D.V., Vivian, A.G., Straliotto, M.C.S. and Poeta, M.P. (2004) Patterns of Retirement Adjustment. Aletheia, 19, 57-68. http://pepsic.bvsalud.org/scielo.php?pid=S1413-03942004000100006\&script=sci_arttext

[50] Ramos, L.R. (2003) Determinant Factors for Healthy Aging among Senior Citizens in a Large City: The Epidoso Project in São Paulo. Cadernos de Saúde Pública, 19, 739-798.

[51] Kenny, G.P., Yardley, J.E., Martineau, L. and Jay, O. (2008) Physical Work Capacity in Older Adults: Implications for the Aging Worker. American Journal of Industrial Medicine, 51, 610-625. http://dx.doi.org/10.1002/ajim.20600

[52] Chan, G., Tan, V. and Koh, D. (2000) Ageing and Fitness to Work. Occupational Medicine, 50, 483-491. http://dx.doi.org/10.1093/occmed/50.7.483

[53] Martinez, M.C. and Latorre, M.R.D.O. (2008) Health and Work Ability of Workers of the Electricity Sector in São Paulo. Ciência \& Saúde Coletiva, 13, 1061-1073. http://dx.doi.org/10.1590/S1413-81232008000300029 